\title{
Characterization of Diarrheagenic Antimicrobial Resistant Escherichia coli Isolated From Pediatric Patients in Tehran, Iran
}

\author{
Maryam Heidary ${ }^{1}$; Hassan Momtaz ${ }^{2, *}$; Mahboobeh Madani ${ }^{1}$ \\ ${ }^{1}$ Department of Microbiology, Falavarjan Branch, Islamic Azad University, Falavarjan, IR Iran \\ 2 Department of Microbiology, Shahrekord Branch, Islamic Azad University, Shahrekord, IR Iran \\ *Corresponding Author: Hassan Momtaz, Department of Microbiology, Shahrekord Branch, Islamic Azad University, Shahrekord, IR Iran. Tel/Fax: +98-3361064, E-mail: hamomtaz@ \\ yahoo.comhamomtaz@iaushk.ac.ir
}

Received: May 20, 2013; Revised: August 19, 2013; Accepted: August 26, 2013

\begin{abstract}
Background: Acute infectious diarrhea is one of the most important causes of morbidity and mortality worldwide.
Objectives: The objective of this study was to characterize antimicrobial resistant diarrheagenic Escherichia coli strains isolated from diarrheic children in Tehran, IR Iran.

Patients and Methods: In total, 550 stool samples from diarrheic pediatric patients, aged less than 60 months, were collected and immediately transferred to the laboratory. Isolation and identification of E. coli strains was done using bacteriological methods. Antimicrobial susceptibility testing was performed using the disk diffusion technique. Multiplex PCR was used to detect aadA1, tetA, tetB, dfrA1, qnr, aac (3)-IV, sul1, blaSHV, CITM, cat1, and cmlA antibiotic resistance genes.

Results: From the total of 550 fecal samples examined, 154 samples (28\%) were positive for diarraheagenic E. coli. High rates of antibiotic resistance were seen against penicillin (100\%), ampicillin (89.6\%) and tetracycline (83.1\%). Resistance against ciprofloxacin was low (28.6\%). The prevalence of different resistance genes in the studied strains varied from $96.10 \%$ for aadA1 gene to $40.25 \%$ for sul1 gene. The frequencies of aadA1, tetA, tetB, dfrA1, qnr, aac(3)-IV, sul1, blaSHV, CITM, cat1, and cmlA genes were $96.10 \%, 85.06 \%, 84.41 \%, 51.94 \%, 72.07 \%, 54.54 \%, 40.25 \%$, $57.79 \%, 90.25 \%, 59.74 \%$ and $60.38 \%$, respectively.

Conclusions: Our results indicated that antibiotic resistance is increasing in diarraheagenic E. coli strains in Iran. It is imperative to develop strategies for prevention and control of resistant organisms. Changes in patterns of resistance against commonly used antibiotics in Iran indicate that an applied surveillance system and introduction of guidelines for appropriate antibiotic prescription are necessary.
\end{abstract}

Keywords:Escherichia coli; child; Multiplex Polymerase Chain Reaction

\section{Background}

Acute infectious diarrhea (AID) is one of the most important causes of morbidity and mortality worldwide. This disease remains a major public health challenge, particularly in developing countries where it is a leading cause of death (1-3). A variety of microorganisms including bacteria, viruses and parasites can be associated with severe AID in children (4-7). Many studies have reported that among the bacterial pathogens, diearrheagenic Escherichia coli (E. coli) (DEC) is one of the most frequent causes of AID in children under five years old in developing countries (8-10). Previous studies have estimated that annually in Iran, diarrhea is responsible for 18 million cases of illness, 12 million medical visits, one million hospital admissions, and more than 500 deaths in children younger than five years old $(10,11)$. Also, according to the Global Burden Disease Report of the World Health Organization (WHO), diarrhea is the second most common cause of mortality in children under five years old (12-15). Microbial resistance to antibiotics due to treatment of bacterial pathogens and extended use of different antibi- otics is an increasing public health problem worldwide. Administration of antimicrobial agents has caused turbulence in the ecological balance between the host and microorganisms. In addition, acquisition of antibiotic resistance by pathogenic bacteria has increased and this may lead to more severe infections $(7,16-19)$. The intestinal E. coli microflora may provide an important reservoir for antibiotic-resistant bacteria and resistance genes. Presences of antimicrobial resistance genes have been reported previously for clinical E. coli isolates from humans and animals $(20,21)$. Genetic mutation and the role of genetic mobile elements such as plasmids, integrons and transposons are the most common ways for antibiotic resistance distribution $(3,8)$. Multidrug resistance to antimicrobial agents among bacterial pathogens is of great concern in clinical settings and is a major public health issue (21). Therefore, the ecological impact of different antimicrobial agents, as well as development of antimicrobial resistance before appearance in pathogenic strains and in clinical infections, could be studied in intestinal $E$. 
coli. Knowledge on antimicrobial resistance of diarrheagenic pathogens is important for selecting the appropriate therapy and necessary for physicians in order to treat infections using appropriate antibiotics $(21,22)$.

\section{Objectives}

The aim of this study was to characterize antimicrobial resistance in DEC strains isolated from pediatric patients in Tehran, IR Iran.

\section{Patients and Methods}

\subsection{Clinical Specimens}

This experimental study was carried out from March 2010 to September 2011. In total, 550 stool samples were collected randomly from children with diarrhea younger than 60 months old. The method of sample collection was simple accidental. These samples were collected from two major hospitals of Tehran, Iran (Baqyiatallah and Peyambar-Azam Hospitals). Information on some clinical and epidemiological features was obtained through questionnaires. These patients presented different types of symptoms including nausea, fever and dysentery. Stool specimens were collected using sterile swabs, and transported to the laboratory at $4^{\circ} \mathrm{C}$ using a cooler with iced-packs. Sample collection was performed with the consent of the children's parent or guardian, and the study was approved by the local bioethical committee of Shahrekord Islamic Azad University. Control subjects included healthy children with no history of diarrhea for at least one month.

\subsection{Isolation of Bacteria}

Three milliliters of each sample was blended with 225 mL of nutrient broth (Merck, Germany) for two minutes at normal speed, using a Stomacher lab blender and incubated at $37^{\circ} \mathrm{C}$ for 24 hours. A $1 \mathrm{~mL}$ sample of the nutrient broth culture was mixed with $9 \mathrm{~mL}$ of MacConkey broth (Merck, Germany) and further incubated at $37^{\circ} \mathrm{C}$ for 24 hours. One loop of each tube was streaked on MacConkey agar (Merck, Germany). A typical purple colony of E. coli from each sample was streaked on a separate eosin methylene blue agar (EMB agar) plate (Merck, Germmany) and incubated at $37^{\circ} \mathrm{C}$ for 24 hours. A metallic green colony from each plate with a typical E. coli morphology was selected and examined by biochemical tests, including hydrogen sulfide, citrate, urease and indol based on the API test system (BioMerieux, Marcy L'Etoile, France) (23).

\subsection{Antibiotic Susceptibility Testing}

All E. coli isolates were tested for susceptibility to penicillin (10 u/disk); tetracycline (30 $\mu \mathrm{g} /$ disk); streptomycin (10 $\mu \mathrm{g} /$ disk); chloramphenicol (30 $\mu \mathrm{g} /$ disk); sulphonamides (100 $\mu \mathrm{g} /$ disk), sulfamethoxazol (25 $\mu \mathrm{g} /$ disk); gentamycin
(10 $\mu \mathrm{g} /$ disk); lincomycin (2 $\mu \mathrm{g} /$ disk); cephalothin $(30 \mu \mathrm{g} /$

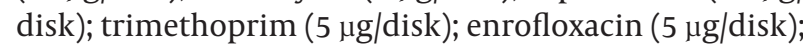
ciprofloxacin ( $5 \mu \mathrm{g} / \mathrm{disk}$ ); ampicillin (10 u/disk); by the Kirby-Bauer disk diffusion method (MAST House, Merseyside, United Kingdom) (24). Resistance break points were those recommended by the Clinical and Laboratory Standards Institute (25), and was reported as sensitive or resistant based on break points. Escherichia coli ATCC 25922 was used as a quality control organism for antimicrobial susceptibility determination.

\subsection{Detection of Antibiotic Resistance Genes}

\subsubsection{DNA Extraction}

DNA extraction was carried out using the boiling method. Briefly, the culture of each isolate was inoculated in Tryptose soy broth (Merck, Germany) and incubated at $37^{\circ} \mathrm{C}$ for 24 hours. Bacteria were harvested from an overnight broth culture and suspended in sterile water (DDW), after which the bacterial suspension was boiled for 10 minutes and chilled on ice and finally the debris were separated by centrifugation. The supernatant was taken as the DNA template for PCR.

\subsubsection{Primers and PCR Conditions}

Multiplex PCR amplification was used to identify 11 antibiotic resistant genes including aadA1 for streptomycin (26); tetA, and tetB for tetracycline (26); dfrA1 for trimethoprim (27); qnr for fluoroquinolone (28); aac(3)-IV for gentamicin; sul1 for sulfonamide; blaSHV for cephalothin; CITM for ampicillin; and cat1 and cmlA for chloramphenicol resistance genes (29). Positive controls for the resistance genes were DNA samples from bacterial isolates previously characterized and sequenced in-house. The primers for all genes are presented in Table 1. Each PCR assay was carried out with a $50 \mu \mathrm{L}$ mixture containing 10X PCR buffer, 2.5 mM MgCl2, 200 mM dNTP(Fermentas, Lithuania) 2.0 U of Taq DNA polymerase (Fermentas, Lithuania), $0.5 \mathrm{mM}$ of each primer set and $3 \mu \mathrm{L}$ of the DNA template. The specificity and optimal concentration of primers was determined experimentally. PCR was carried out on a thermocycler (Eppendrof Mastercycler 5330; Eppendorf-Nethel-Hinz GmbH, Hamburg, Germany) using the following cycle: after an initial denaturation cycle of seven minutes at $94^{\circ} \mathrm{C}$, the reaction mixes were subjected to 32 amplification cycles of 60 seconds at $95^{\circ} \mathrm{C}$ and 70 second at $55^{\circ} \mathrm{C}$ and two minutes at $72^{\circ} \mathrm{C}$, and final extension of five minutes at $72^{\circ} \mathrm{C}$. The reference strains served as the positive control and distilled water as the negative control. The PCR products were then separated by electrophoresis on a $2.0 \%$ agarose gel, stained with ethidium bromide and visualized using UV illumination. A $100 \mathrm{bp}$ DNA molecular marker (Fermentas, Lithuania) was used to determine the size of the amplicons. 
Heidary M et al.

\begin{tabular}{|c|c|c|c|c|}
\hline Primer & Sequence & Amplification Size & Antibiotic Resistance & Reference \\
\hline \multicolumn{5}{|l|}{ aadA1 } \\
\hline $\mathrm{F}$ & TATCCAGCTAAGCGCGAACT & 447 & streptomycin resistance & (26) \\
\hline $\mathrm{R}$ & ATTTGCCGACTACCTTGGTC & & & \\
\hline \multicolumn{5}{|l|}{ tetA } \\
\hline $\mathrm{F}$ & GGTTCACTCGAACGACGTCA & 577 & tetracycline resistance & $(26)$ \\
\hline $\mathrm{R}$ & CTGTCCGACAAGTTGCATGA & & & \\
\hline \multicolumn{5}{|l|}{ tetB } \\
\hline $\mathrm{F}$ & CCTCAGCTTCTCAACGCGTG & 634 & tetracycline resistance & $(26)$ \\
\hline $\mathrm{R}$ & GCACCTTGCTGATGACTCTT & & & \\
\hline \multicolumn{5}{|l|}{ dfrA1 } \\
\hline $\mathrm{F}$ & GGAGTGCCAAAGGTGAACAGC & 367 & $\begin{array}{l}\text { trimethoprim resis- } \\
\text { tance }\end{array}$ & $(27)$ \\
\hline $\mathrm{R}$ & GAGGCGAAGTCTTGGGTAAAAAC & & & \\
\hline \multicolumn{5}{|l|}{ Qnr } \\
\hline $\mathrm{F}$ & GGGTATGGATATTATTGATAAAG & 670 & fluoroquinolone & $(28)$ \\
\hline $\mathrm{R}$ & CTAATCCGGCAGCACTATTTA & & resistance & \\
\hline \multicolumn{5}{|c|}{$\operatorname{aac}(3)-I V$} \\
\hline $\mathrm{F}$ & CTTCAGGATGGCAAGTTGGT & 286 & gentamicin resistance & (29) \\
\hline $\mathrm{R}$ & (TCATCTCGTTCTCCGCTCAT & & & \\
\hline \multicolumn{5}{|l|}{ Sul1 } \\
\hline $\mathrm{F}$ & TTCGGCATTCTGAATCTCAC & 822 & sulfonamide resistance & (29) \\
\hline $\mathrm{R}$ & ATGATCTAACCCTCGGTCTC & & & \\
\hline \multicolumn{5}{|l|}{ blaSHV } \\
\hline $\mathrm{F}$ & TCGCCTGTGTATTATCTCCC & 768 & cephalothin resistance & (29) \\
\hline $\mathrm{R}$ & CGCAGATAAATCACCACAATG & & & \\
\hline \multicolumn{5}{|l|}{ CITM } \\
\hline $\mathrm{F}$ & TGGCCAGAACTGACAGGCAAA & 462 & ampicillin resistance & (29) \\
\hline $\mathrm{R}$ & TTTCTCCTGAACGTGGCTGGC & & & \\
\hline \multicolumn{5}{|l|}{ ereA } \\
\hline $\mathrm{F}$ & GCCGGTGCTCATGAACTTGAG & 419 & erythromycin & (29) \\
\hline $\mathrm{R}$ & CGACTCTATTCGATCAGAGGC & & resistance & \\
\hline \multicolumn{5}{|l|}{ cat1 } \\
\hline $\mathrm{F}$ & AGTTGCTCAATGTACCTATAACC & 547 & chloramphenicol & (29) \\
\hline $\mathrm{R}$ & TTGTAATTCATTAAGCATTCTGCC & & resistance & \\
\hline \multicolumn{5}{|l|}{ CmlA } \\
\hline $\mathrm{F}$ & CCGCCACGGTGTTGTTGTTATC & 698 & chloramphenicol & (29) \\
\hline $\mathrm{R}$ & CACCTTGCCTGCCCATCATTAG & & resistance & \\
\hline
\end{tabular}

\subsection{Statistical Analysis}

The data were analyzed using the SPSS (statistical package for the social sciences) software and P values were calculated using Chi-square and Fisher's exact tests to determine significant relationships between various criteria and distribution of antibiotic resistance properties of STEC strains isolated from diarrheic pediatric patients. A P value less than 0.05 was considered statistically significant.

\subsection{Ethical Issues}

The present study was accepted by the ethical commit- 
tee of the Baqyiatallah and Peyambar-Azam Hospitals of Tehran, Iran and Microbiology and Infectious Diseases Center of the Islamic Azad University of Shahrekord, Iran. Written informed consent was obtained from all of the studied patients or their parents. The agreement between the Islamic Azad University of Shahrekord and the two mentioned hospitals had been signed before sampling (on 10th of April and 15th of April 2013).

\section{Results}

A total of 550 rectal swabs were examined for the presence of diarrheagenic E. coli strains isolated from children between the ages of one month to five years. Totally, 154 samples (28\%) were positive for diarrheagenic E. coli. The greatest rates for isolates recovery were from the 13-24 month age group (38.3\%), followed by the 1-12 month age group (23.38\%) (Table 2$)$. Incidence of nausea, fever and dysentery clinical signs were 69 (44.8\%), $64(41.6 \%)$ and 21 (13.6\%), respectively. From a total of 154 positive diarrheagenic E. coli strains, 74 (48\%) and 80 (51.9\%) were isolated from female and male patients, respectively (Table 2$)$. In total, 47 (30.5\%), 62 (40.2\%), and $45(29.2 \%)$ positive specimens were isolated from the samples, which were collected during spring, summer and fall, respectively. Antibiotic susceptibility testing showed high antibiotic resistance rates against penicillin (1002\%), ampicillin (89.6\%), tetracycline (83.1\%), trimethoprim (71.4\%) and streptomycin (50.6\%) antibiotics. Antibiotic resistance rates against enrofloxacin (33.1\%) and ciprofloxacin $(28.6 \%)$ were the minimum. Table 3 shows the complete results of antimicrobial resistance among diarrheagenic E. coli.

All of the isolates had resistance to more than one antibiotic. There was a significant statistical difference for incidence of bacteria between 13-24 month old and 37-48 month old pediatrics $(\mathrm{P}<0.05)$. Also, differences were significant $(\mathrm{P}<0.05)$ for bacterial resistance between ampicillin and penicillin with ciprofloxacin and enrofloxacin $(\mathrm{P}<0.05)$. However, there were no significant statistical differences between the sex of the patients and rates of antibiotic resistance. There were no significant differences for incidence of bacteria between the male and females. The results obtained from analysis of the antimicrobial resistance genes showed that 11 resistance genes were identified in all E. coli strains. The distribution of resistance genes among E. coli isolates is summarized in Table 4 . The prevalence of different resistance genes varied from $96.10 \%$ for the aadA1 gene to $40.25 \%$ for the sul1 gene. Trimethoprim resistance attributed to dfrA1 gene was found in $51.94 \%$ of the strains. Of the tetracycline resistant isolates, $85.06 \%$ were positive for tetA genes while $84.41 \%$ were positive for tetB. The catI and cmlA genes were detected in $59.74 \%$ and $60.38 \%$ of chloramphenicol resistant isolates, respectively. The SHV $\beta$-lactamase gene was identified in $57.79 \%$ (89/154) of cephalithin resistant isolates. For ampicillin resistance, $90.25 \%$ of the isolates were positive for the CITM gene. The sul1 gene was detected in $40.25 \%$ of sulfonamide resistant isolates. The aac(3)IV gene which codes resistance against gentamycin was found in $54.54 \%$ of isolates (Table 4 ).

Table 2. Description of Different Criteria of Patients in Order of Gender $(\mathrm{n}=154)^{\mathrm{a}}$

\begin{tabular}{lccc}
\hline $\begin{array}{l}\text { Criteria (Age, Season and } \\
\text { Clinical Signs) }\end{array}$ & Male & Female & Results \\
\hline $\mathbf{1 - 1 2}$ & 20 & 16 & $36(23.4)$ \\
$\mathbf{1 3 - 2 4}$ & 31 & 28 & $59(38.3)$ \\
$\mathbf{2 5 - 3 6}$ & 11 & 13 & $24(15.6)$ \\
\hline $\mathbf{3 7 - 4 8}$ & 6 & 10 & $16(10.4)$ \\
\hline $\mathbf{4 9 - 6 0}$ & 12 & 7 & $19(11.7)$ \\
\hline Spring & 23 & 24 & $47(30.5 \%)$ \\
\hline Summer & 30 & 32 & $62(40.2 \%)$ \\
\hline Fall & 24 & 21 & $45(29.2 \%)$ \\
\hline Nausea & 36 & 33 & $69(44.8 \%)$ \\
\hline Fever & 36 & 28 & $64(41.6 \%)$ \\
\hline Dysentery & 12 & 9 & $21(13.6 \%)$ \\
\hline
\end{tabular}

a Data are presented as No.(\%).

Table 3. Antibiotic Resistance Profile of Diarrheagenic E. coli in Iran (Disk Diffusion Method) ( $\mathrm{n}=154)$

\begin{tabular}{lcccccccccccccc}
\hline E. coli & P10 & TE30 & S10 & C30 & SXT & GM10 & E15 & NFX5 & L2 & CF30 & CIP5 & TMP5 & AM10 & SF100 \\
\hline Total & 142 & 128 & 78 & 92 & 60 & 79 & 111 & 51 & 50 & 88 & 44 & 62 & 138 & 83 \\
\hline
\end{tabular}

Table 4. Distribution of Antimicrobial Resistance Genes in Diarrheagenic E. coli in Iran $(n=154)$

\begin{tabular}{lcccccccccccc}
\hline $\begin{array}{l}\text { Total Positive } \\
\text { Samples }\end{array}$ & \multicolumn{10}{c}{ Antibiotic Resistance Genes, \% } \\
\cline { 2 - 18 } & aadA1 & tetA & tetB & dfrA1 & qnr & aac(3)-IV & sul1 & blaSHV & CITM & cat1 & cmlA \\
\hline E. coli & 148 & 131 & 130 & 80 & 111 & 84 & 62 & 89 & 139 & 92 & 93 \\
& $(96.10)$ & $(85.06)$ & $(84.41)$ & $(51.94)$ & $(72.07)$ & $(54.54)$ & $(40.25)$ & $(57.79)$ & $(90.25)$ & $(59.74)$ & $(60.38)$ \\
\hline
\end{tabular}




\section{Discussion}

DEC has been identified as one of commensally pathogenic bacteria, which cause diarrhea among infants and children, especially in developing countries $(4,30,31)$. Many investigations have been previously done in order to survey the prevalence of DEC in different countries. Albert et al., (32) found that the frequency of DEC in Bangladeshi children was higher than $40 \%$. In another study, Shehabi et al. (33) reported that the prevalence of DEC isolates was $34 \%$ among children with diarrhea in Jordan. In the present study, of the 550 stool samples examined, DEC strains were isolated from $28 \%$ of cases. This finding is interesting however a previous study in Tehran reported the prevalence rate of DEC as $54 \%$ (3). The possessive increase in antimicrobial resistance of bacterial strains is becoming of concern, particularly in developing countries (34). The observed antimicrobial resistance may be a result of overuse and misuse of different antibiotics in infection treatments $(1,25)$. Commensal bacteria are the main source of resistance genes for pathogenic bacteria (34). The DEC is one of these commensal bacteria, and $E$. coli have been often used as useful indicators for survey of the selective pressure of antimicrobial agents and distribution of acquired resistance genes $(6,7,10,12,14,25)$. Previous studies have indicated that the majority of DEC strains have shown antibiotic resistance at least against one of the following antibiotics sulfonamide, cotrimoxazole, and ampicillin (18). In developing countries, some antibiotics are widely used to treat infectious diseases because of their low cost and availability $(14,19)$. Currently, trimethoprim-sulfamethoxazole, ampicillin and tetracycline are frequently used to treat diarrhea (7).

In our study, a high frequency of DEC antimicrobial resistance to commonly used antibiotics such as ampicillin (89.6\%) was observed. This finding is comparable to previously reported studies on children from Peru and Bolivia, Vietnam, Tanzania, Mexico, Argentina and Mozambique that reported a prevalence of ampicillin resistance of more than 70\% in DEC isolates (2). In another study (7) in Honoi, Vietnam, DEC strains exhibited different levels of resistance to ampicillin (86.4\%), chloramphenicol (77.2\%) and trimethoprim-sulfamethoxazole (19.1\%). In another study, antibiotic resistance rates among Egyptian DEC isolates were $68.2 \%, 57.2 \%$ and $24.2 \%$ for ampicillin, trimethoprim-sulfamethoxazole and ampicillin-sulbactam, respectively (35). Bouzari et al. (19) found high resistance rates against sulfamethoxazole-trimethoprim, tetracycline and chloramphenicol in DEC strains isolated from Tehran, IR Iran. With the exception of sulfamethoxazole, our findings are in agreement with the report of Bouzari et al. (19). Many studies indicate that multidrug resistant E. coli are widespread among the DEC strains and occurrence of resistant DEC could be because of environmental conditions, including transmission of resistant isolates from adults to children, or from animals to humans (3). Multidrug resistant DEC strains have been reported in previous studies $(8,11,12)$. EI Metwally et al. (36) reported that $56 \%$ of DEC isolates were multidrug resistant (simultaneous resistance against SXT, ampicillin and tetracycline). Also, Souza et al. (37) found a high rate of antimicrobial drug-resistance (65\%) among DEC strains isolated from children. In our study, all of the isolates were multidrug resistant. Our study revealed a high prevalence of multidrug antibiotic resistance among E. coli isolates, because of overuse and misuse of antibiotics to treat diarrheal diseases in Iran. The main factors for dissemination of resistance genes are mobilizable plasmids, self-transmissible plasmids and conjugative transposons (38).

In this present study, among tetracycline resistance strains, $85.06 \%$ and $84.41 \%$ harbored tetA and tetB gene, respectively. Gene carriage for ampicillin resistance gene (CITM) was observed in $90.25 \%$ of ampicillin resistant isolates. However, this speculation does not apply to streptomycin, which has had limited clinical use for many years; nevertheless, the high rate of resistance (78.2\%) to this drug has persisted (38). Possible explanation for the persistence of resistance to these drugs includes the properties of the mobile elements on which the determinants are carried, and the potential selection pressures other than antibiotics for human medical use (3). According to the result of this study, resistance to ampicillin, tetracycline, trimethoprim, and chloramphenicol were very common in DEC. It seems that the patients infected with E. coli strains, could be a potential source for antibiotics resistance genes (34).

In the recent years, molecular methods have been reported as rapid and sensitive techniques. Multiplex PCR is a rapid and specific diagnostic method for simultaneous detection of several virulence and antimicrobial resistance genes in one PCR reaction (39-41). Studies have been carried out in order to study the prevalence of antibiotic resistance genes in E. coli isolates of animal and human samples. Momtaz et al. (42) detected tetA, tetB, dfrA1, qnrA, catA1, cmlA, sul1 and ereA genes in E. coli isolated from slaughtered commercial chickens by multiplex PCR. They reported the distribution of studied genes as: tetA and tetB (52.63\%), dfrA1, qnrA, catA1 and cmlA (36.84\%) and sul1 and ereA (47.36\%). Ahmed et al. (43) studied the frequency of antimicrobial resistance genes in equine fecal E. coli strains by PCR in North West England. They found high rates of dfr, tem beta-lactamase, tet and cat genes (93\%, 91\%, 89\% and 73.5\%, respectively). In the present study, the occurrence of 11 antibiotic resistance genes in DEC strains was investigated by multiplex PCR. The frequency of aadA1, tetA, tetB, dfrA1, qnr, aac(3)-IV, sul1, blaSHV, CITM, cat1, and cmlA genes were in $96.10 \%, 85.06 \%$, $84.41 \%$, 51.94\%, 72.07\%, 54.54\%, 40.25\%, 57.79\%, 90.25\%, $59.74 \%$, and $60.38 \%$, respectively.

According to the progressive increase in antibiotic resistance among enteric pathogens, particularly in developing countries, it is imperative to implement strategies to prevent and control the emergence and spread of resistant organisms by inexpensive, sensitive, and simple 
methods. Practitioners should pay more attention to antibiotic prescription especially that related to diarrhea in children.

\section{Acknowledgements}

The authors would like to thank Dr. Farhad Safarpoor Dehkordi, Dr. E. Tajbakhsh, and Mr. M. Momeni at the Biotechnology Research Center of the Islamic Azad University of Shahrekord for their important technical and clinical support.

\section{Authors' Contribution}

Hassan Momtaz and Maryam Heidary designed the research and contributed equally to this work; Mahboobeh Madani analyzed the data and edited the paper.

\section{Financial Disclosure}

The authors declare that they have no competing interests.

\section{Funding/Support}

This work was supported by the Islamic Azad University, Falavarjan Branch-Iran grant No. 91/8796.

\section{References}

1. Usein CR, Tatu-Chitoiu D, Ciontea S, Condei M, Damian M Escherichia coli pathotypes associated with diarrhea in Romanian children younger than 5 years of age. Jpn J Infect Dis. 2009;62(4):289-93.

2. Ochoa TJ, Ruiz J, Molina M, Del Valle LJ, Vargas M, Gil AI, et al. High frequency of antimicrobial drug resistance of diarrheagenic Escherichia coli in infants in Peru. Am J Trop Med Hyg. 2009;81(2):296-301.

3. Jafari F, Hamidian M, Rezadehbashi M, Doyle M, SalmanzadehAhrabi S, Derakhshan F, et al. Prevalence and antimicrobial resistance of diarrheagenic Escherichia coli and Shigella species associated with acute diarrhea in Tehran, Iran. Can J Infect Dis Med Microbiol. 2009;20(3):e56-62.

4. Wilson G, Easow JM, Mukhopadhyay C, Shivananda PG. Isolation \& antimicrobial susceptibility of Shigella from patients with acute gastroenteritis in Western Nepal. Indian J Med Res. 2006;123(2):145-50.

5. Bryce J, Boschi-Pinto C, Shibuya K, Black RE, W. H. O. Child Health Epidemiology Reference Group. WHO estimates of the causes of death in children. Lancet. 2005;365(9465):1147-52.

6. Niehaus MD, Moore SR, Patrick PD, Derr LL, Lorntz B, Lima AA, et al. Early childhood diarrhea is associated with diminished cognitive function 4 to 7 years later in children in a northeast Brazilian shantytown. Am J Trop Med Hyg. 2002;66(5):590-3.

7. Nguyen TV, Le PV, Le CH, Weintraub A. Antibiotic resistance in diarrheagenic Escherichia coli and Shigella strains isolated from children in Hanoi, Vietnam. Antimicrob Agents Chemother. 2005;49(2):816-9.

8. Yang CM, Lin MF, Lin CH, Huang YT, Hsu CT, Liou ML. Characterization of antimicrobial resistance patterns and integrons in human fecal Escherichia coli in Taiwan. Jpn $J$ Infect Dis. 2009;62(3):177-81.

9. Vila J, Vargas M, Casals C, Urassa H, Mshinda H, Schellemberg D, et al. Antimicrobial resistance of diarrheagenic Escherichia coli isolated from children under the age of 5 years from Ifakara, Tanzania. Antimicrob Agents Chemother.1999;43(12):3022-4.

10. Mansouri S, Shareifi S. Antimicrobial resistance pattern of Escherichia coli causing urinary tract infections, and that of human fecal flora, in the southeast of Iran. Microb Drug Resist. 2002;8(2):123-8.

11. Kalantar E, Soheili F, Salimi H, Soltan Dallal MM. Frequency, an timicrobial susceptibility and plasmid profiles of Escherichia coli pathotypes obtained from children with acute diarrhea. $J J$ Microbiol. 2011;4(1):23-8.

12. Alizadeh AH, Behrouz N, Salmanzadeh S, Ranjbar M, Azimian MH, Habibi E, et al. Escherichia coli, Shigella and Salmonella species in acute diarrhoea in Hamedan, Islamic Republic of Iran. East Mediterr Health J. 2007;13(2):243-9.

13. Keskimaki M, Mattila L, Peltola H, Siitonen A. Prevalence of diarrheagenic Escherichia coli in finns with or without diarrhea during a round-the-world trip. J Clin Microbiol. 2000;38(12):4425-9.

14. Jafari F, Shokrzadeh L, Hamidian M, Salmanzadeh-Ahrabi S, Zali MR. Acute diarrhea due to enteropathogenic bacteria in patients at hospitals in Tehran.Jpn J Infect Dis. 2008;61(4):269-73.

15. Mandomando IM, Macete EV, Ruiz J, Sanz S, Abacassamo F, Valles $\mathrm{X}$, et al. Etiology of diarrhea in children younger than 5 years of age admitted in a rural hospital of southern Mozambique. Am J Trop Med Hyg. 2007;76(3):522-7.

16. Bartoloni A, Cutts F, Leoni S, Austin CC, Mantella A, Guglielmetti $P$, et al. Patterns of antimicrobial use and antimicrobial resistance among healthy children in Bolivia. Trop Med Int Health. 1998;3(2):116-23.

17. Estrada-Garcia T, Cerna JF, Paheco-Gil L, Velazquez RF, Ochoa TJ, Torres J, et al. Drug-resistant diarrheogenic Escherichia coli, Mexico. Emerg Infect Dis. 2005;11(8):1306-8.

18. Binsztein N, Picandet AM, Notario R, Patrito E, De Lesa ME, De Petris A, et al. [Antimicrobial resistance among species of Salmonella, Shigella, Escherichia, and aeromonas isolated from children with diarrhea in 7 Argentinian centers]. Rev Latinoam Microbiol. 1999;41(3):121-6.

19. Bouzari S, Jafari A, Zarepoor M. Distribution of genes encoding toxins and antibiotic resistance patterns in diarrheagenic Escherichia coli isolates in Tehran. East Med Heath J. 2007;13:287-93.

20. Pickering LK. Antimicrobial resistance among enteric pathogens. Semin Pediatr Infect Dis. 2004;15(2):71-7.

21. Okeke IN, Aboderin OA, Byarugaba DK, Ojo KK, Opintan JA. Growing problem of multidrug-resistant enteric pathogens in Africa. Emerg Infect Dis. 2007;13(11):1640-6.

22. Barbosa TM, Levy SB. Differential expression of over 60 chromosomal genes in Escherichia coli by constitutive expression of MarA. J Bacteriol. 2000;182(12):3467-74.

23. AOAC International.. Official methods of analysis of AOAC International. 16th edUSA: AOAC International, Gaithersburg; 1995.

24. Bauer AW, Kirby WM, Sherris JC, Turck M. Antibiotic susceptibility testing by a standardized single disk method. Am J Clin Pathol. 1966;45(4):493-6.

25. Cowan ST, Steel KJ, (second edition).. Identification of medical bacteria. 2nd edCambridge: University press; 1974.

26. Randall LP, Cooles SW, Osborn MK, Piddock LJ, Woodward MJ Antibiotic resistance genes, integrons and multiple antibiotic resistance in thirty-five serotypes of Salmonella enterica isolated from humans and animals in the UK. J Antimicrob Chemother. 2004;53(2):208-16.

27. Toro CS, Farfan M, Contreras I, Flores O, Navarro N, Mora GC, et al. Genetic analysis of antibiotic-resistance determinants in multidrug-resistant Shigella strains isolated from Chilean children. Epidemiol Infect. 2005;133(1):81-6.

28. Mammeri H, Van De Loo M, Poirel L, Martinez-Martinez L, Nordmann P. Emergence of plasmid-mediated quinolone resistance in Escherichia coli in Europe. Antimicrob Agents Chemother. 2005;49(1):71-6.

29. Van TT, Chin J, Chapman T, Tran LT, Coloe PJ. Safety of raw meat and shellfish in Vietnam: an analysis of Escherichia coli isolations for antibiotic resistance and virulence genes. Int J Food Microbiol. 2008;124(3):217-23.

30. Maira-Litran T, Allison DG, Gilbert P. Expression of the multiple antibiotic resistance operon (mar) during growth of Escherichia coli as a biofilm. J Appl Microbiol. 2000;88(2):243-7.

31. Jousilahti P, Madkour SM, Lambrechts T, Sherwin E. Diarrhoeal disease morbidity and home treatment practices in Egypt. Public 


\section{Heidary M et al.}

Health. 1997;111(1):5-10.

32. Albert MJ, Faruque SM, Faruque AS, Neogi PK, Ansaruzzaman M, Bhuiyan NA, et al. Controlled study of Escherichia coli diarrheal infections in Bangladeshi children. J Clin Microbiol. 1995;33(4):973-7.

33. Shehabi AA, Bulos NK, Hajjaj KG. Characterization of diarrhoeagenic Escherichia coli isolates in Jordanian children. Scand J Infect Dis. 2003;35(6-7):368-71.

34. van den Bogaard AE, Stobberingh EE. Epidemiology of resistance to antibiotics. Links between animals and humans. Int J Antimicrob Agents. 2000;14(4):327-35.

35. Putnam SD, Riddle MS, Wierzba TF, Pittner BT, Elyazeed RA, ElGendy A, et al. Antimicrobial susceptibility trends among Escherichia coli and Shigella spp. isolated from rural Egyptian paediatric populations with diarrhoea between 1995 and 2000. Clin Microbiol Infect. 2004;10(9):804-10.

36. EI Metwally HA, Ibrahim HA, El-Athamna MN, Amer MA. MultiplexPCR for detection of diarrheagenic Escherichia coli in Egyptian children. J Med Sci. 2007;7:255-62.

37. Souza TB, Morais MB, Tahan S, Melli LC, Rodrigues MS, Scaletsky IC. High prevalence of antimicrobial drug-resistant diarrheagenic Escherichia coli in asymptomatic children living in an ur- ban slum. J Infect. 2009;59(4):247-51.

38. Brueggemann AB. Antibiotic resistance mechanisms among pediatric respiratory and enteric pathogens: A current update. Pediatr Infect Dis J. 2006;25(10):969-73.

39. Toma C, Lu Y, Higa N, Nakasone N, Chinen I, Baschkier A, et al Multiplex PCR assay for identification of human diarrheagenic Escherichia coli. JClin Microbiol. 2003;41(6):2669-71.

40. Vidal R, Vidal M, Lagos R, Levine M, Prado V. Multiplex PCR for diagnosis of enteric infections associated with diarrheagenic Escherichia coli. JClin Microbiol. 2004;42(4):1787-9.

41. Aranda KR, Fabbricotti SH, Fagundes-Neto U, Scaletsky IC. Single multiplex assay to identify simultaneously enteropathogenic, enteroaggregative, enterotoxigenic, enteroinvasive and Shiga toxin-producing Escherichia coli strains in Brazilian children. FEMS Microbiol Lett. 2007;267(2):145-50.

42. Momtaz H, Rahimi E, Moshkelani S. Molecular detection of antimicrobial resistance genes in E. coli isolated from slaughtered commercial chickens in Iran. Vet Med. 2012;57(4):193-7.

43. Ahmed MO, Clegg PD, Williams NJ, Baptiste KE, Bennett M. Antimicrobial resistance in equine faecal Escherichia coli isolates from North West England. Ann Clin Microbiol Antimicrob. 2010;9:12. 